\title{
UNDERSTANDING THE CONCEPTS OF ISLAMIC WISDOM AND ITS EFFECTS ON THE FORMATION OF MOSQUE ARCHITECTURE
}

\author{
Sina Sattari Sarbangholi ${ }^{\bowtie 凶}$ and Mohammad Reza Pakdelfard ${ }^{\bowtie}$ \\ ${ }^{1}$ PhD student of Architecture, Architecture Department, Islamic Azad University, Tabriz Branch, Tabriz, Iran \\ ${ }^{2}$ Assistant Professor, Department of Architecture, Tabriz Branch, Islamic Azad University, Tabriz, Iran
}

\section{Review Article \\ PII: S238315532000006-9 \\ Received: 19 Aug. 2020 \\ Revised: 11 Dec. 2020 \\ Published: 15 Dec. 2020}

Corresponding author:

Sina Sattari Sarbangholi

E-mail: sina.sattari89@gmail.com

\begin{abstract}
Man, who is an innate being, needs a place to communicate with his Creator, which has celestial and spiritual characteristics that make it possible to experience the ascension of the soul and its connection to the eternal universe. Among the divine religions, Islam has given the most importance to the social aspect of worship, the place that has made this serious matter possible is of great importance. Therefore, mosques have a high status, they are the beating heart of Islamic cities and the most important and best places should be provided for mosques. The first step taken by the Prophet Muhammad (PBUH) after the formation of his government in Medina was the construction of the Quba Mosque, which became the original model of all mosques. In addition to the Islamic spirit, this mosque also had an Islamic identity because it had an Islamic body. The religion of Islam reincarnated the Islamic spirit into the body of Iranian structures upon its arrival in Iran. It is a fact that the newborn replaced the spirit of buildings and inelegance (Zoroastrian temples and shrines). That is, the Islamic spirit flowed in the Iranian vessel. Many mosques that were not built on fire temples and shrines retained the same Iranian body with Islamic spirit, so the Iranian identity was represented in the form of mosques.
\end{abstract}

KEYWORDS: Islamic Art Wisdom, Mosque, Islam, Iranian Architecture

\section{INTRODUCTION}

Wisdom literally means a kind of solid work which is flawless. Wisdom means a verdict, a verdict that is immutable, and a firm verdict that is inviolable in rational knowledge. Some people consider wisdom to mean science and knowledge and a manifestation of philosophy and mysticism, but it should be known that wisdom is different from philosophy, but mysticism can be placed in the realm of wisdom. In fact, wisdom is based on intuitive and acquired sciences, and a sage is one who recognizes the truth and learns the Shari'a sciences, the Tariqa sciences, and the truth and argument. The wisdom of religion and law is the God who has no limits. A sage can be a Muslim, a Christian, a Jew, and a follower of any religion or profession. Perhaps it can be said that the sage can master all the sciences and use them to reach the truth. Socrates is one of those thinkers who reject knowledge in its sensory sense. According to him, people should seek virtue and wisdom instead of personal interests. In fact, Socrates' view of wisdom is insight into the truth that is good for human beings and leads to the health and harmony of the soul. Plato is also one of the thinkers who, while rejecting the sensory view of art, has a negative view. He believes that the artist imitates nature with a sensory vision. Plato's view of wisdom is a kind of deep knowledge of the universe and truth. Aristotle, a student of Plato's school, struggles with sensory perceptions like his professors, and acquires the concept of wisdom in this path. In fact, Aristotle equates wisdom and understanding of the supernatural. Aristotle believes that "a philosopher or lover of wisdom is one who seeks knowledge about the ultimate cause and nature of things and reality and wants knowledge for knowledge itself. In his view, wisdom discusses the principles and primary causes of things, and therefore general knowledge is at the highest level, and wisdom is the farthest science from the senses, the most abstract, and therefore the most difficult science, since it requires the most thought". Ibn Sina considers wisdom mainly as a way to understand the truth of facts and believes that through it, man achieves everything in the world. Muhyiddin Ibn Arabi, the founder of theoretical mysticism, considers the evolution of the soul. Mulla Sadra, the philosopher 
of the reconciliation of reason and love, considers wisdom as a special method that leads the human soul to excellence in order to achieve the highest degrees of happiness.

\section{The wisdom of Islamic architecture}

Spiritual teachings and cultural beliefs are the foundation of a valuable and dynamic architecture. Therefore, recognizing the glorious achievements of Islamic architecture will not be possible without knowing the basics of thought and social infrastructure. Those who unconsciously call Islamic architecture independent of spirituality and wisdom, subconsciously block the path of its progress and excellence. In order to better understand this evolutionary process, it should be borne in mind that "the ancient and mysterious architecture of Iran cannot be understood without the literature and culture of the people who retained its clay and color" $[1,2]$.

\section{Pure Iranian architecture and wisdom}

Islamic architecture is one of the greatest manifestations of the emergence of an artistic truth in the material body. Islamic architecture, as one of the largest branches of Islamic art, has been able to institutionalize a large part of the characteristics of Islamic art in the context of time and during different periods. Historically, architecture is the first art that adapts its ability to artistic concepts and is used by Muslims. The acceptance of Muslims to this art caused it to introduce Islamic religious concepts as the only Islamic for years art. This went so far that for most people, when hearing the word Islamic art, the first thing that comes to mind is Islamic architecture [4].

Although many other methods of Islamic architecture have been greatly influenced by indigenous and historical characteristics, Iranian Islamic architecture is one of the most important and successful schools of Islamic architecture. Because over the years, it has shown an upward trend and an evolutionary process of happiness. The methods of Iranian architecture have each complemented the methods of their predecessors and have evolved over the years without the slightest disturbance. The geographical location of Iran has been very effective in this regard because on one hand, Iranians were among the first tribes to convert to Islam and on the other hand, many other nations and countries have achieved this success through Iran. The expansion of geography and cultural richness of the Iranian people has also been very effective in this regard [5].

\section{Islamic architecture; the border of art and spirituality}

Few people can be found who set foot on an Islamic building and do not drown in its infinite space. They are all manifestations of the supernatural in nature. In Islamic art, nothing should separate the distance between man and the unseen presence of God. That is why the direction of mosques in any part of the world is towards the Qaba. That is, the direction is beyond the place where it is built. Thus the concept of time for such a building whose direction is out of place is different from countable time. This is where Islamic art is tied to spirituality [6].

\section{The wisdom of mosque architecture}

Architecture is one of the Islamic arts that incorporates the identity characteristics of Islam and has almost all the characteristics of religious art. In Islamic lands, houses were built to suit the short life of human beings. For the architecture of houses, more attention was paid to the logical functions of the building than to its immortality, and perhaps this is why the houses of the past are remained less, except for a few that are also spiritually protected, such as Fatimah's house (PBUH) in Medina or the house of Imam Ali (PBUH) in Kufa, which again has been maintained by the spiritual wisdom of the building. But the houses of God have been separated from this. God Himself is eternal, so His place of worship must also be eternal. For this reason, in Islam, the architecture of mosques has been given much importance and the architecture of mosques is adorned with the most beautiful arts. In fact, mosques are a manifestation of Islamic art [7].

\section{Judicial view of the architecture of God's houses}

Islamic art is a legal art. The only knowledge that can understand and express Islamic art is wisdom. Architecture and related decorations have a very strong place in Islamic arts. The basis of Islamic architecture is based on wisdom. The wisdom of Islamic architecture, especially the architecture of mosques, can be studied in both external and internal dimensions. All the requirements and functions of mosques are wise both outwardly and inwardly. It is also possible to observe the outward and inward wisdom of the architecture of mosques in terms of the use of the symbol, physical and functional functions, and the outward and inward characteristics of the constituent parts of the building. The historical course of mosque 
architecture itself illuminates the existence of wisdom in its transcendent meaning $[8,9]$.

\section{Mosque, the manifestation of the wisdom of Islamic art}

Muslim artisans and artists, due to the spiritual function of the mosque, use all their efforts and creativity to make the mosque more beautiful and stronger. Paying attention to the philosophy of the mosque and its status in the sight of God caused artists to pay special attention to this holy place. Due to the main function of the mosque, which is the closeness of the servant to the Creator, it is very necessary to pay attention to the philosophical principles and foundations of Islamic art. As stated in the discussion of sacred art, Islamic art, in addition to the artist's freedom to use his creativity, has strict limits and rules that not only do not block the way for the Muslim artist; They rather, open the window to a world that is much more beautiful and valuable than the tangible world. Early Islamic mosques were very simple and unpretentious mosques with a rectangular plan and a columned nave without any decoration, but with the growth and geographical development of Islam and the creation of social security and stability in the Islamic regions and the growth and prosperity of its economy, elegant decorations were added to the structure of the mosques which helped a lot in expressing the esoteric meaning of the mosque in the form of its material appearance. Special attention to mosques and their decorations caused mosques to shine as a jewel in Islamic art. However, issues such as climatic conditions, geographical location and cultural conditions prevailing in each region created a special form of mosque architecture.

The structure of the mosque is designed and built in an excellent and spiritual way. The floor of the mosque is paved with the most beautiful and best stones. The use of decorations including Marquetry tiles, seven-color and enamel tiles, and the use of beautiful Stuccos on the walls of courtyards and Shabestans are reminiscent of God's paradise. The use of the best decorations in the sanctuary of the mosque, the most pioneering part towards the Kaaba of God, shows its importance and, in simpler language, a collection of artistic creations in the construction of the house of God. All this is to create a ground for the discovery of intuition so that the Muslim man can feel peace and beauty in the house of God. Gathering Quranic books in a very concise and effective way with Kufic, Thuluth and Naskh scripts, which invites the eye to relax in the azure space of the mosque, is a tool to manifest the esoteric meaning of the mosque. The inscriptions always remind the praying man of God and manifest the true meaning of the Qur'an in his mind so that he understands the incomparable power of God. The patterns and decorations create a harmonious melody and rhythm that is very useful for understanding the spiritual state of the mosque. In general, it should be acknowledged that mosques are in the highest position of Islamic art and have always occupied the minds of a large number of artists and put their taste, initiative and creativity into action, so that the greatest masterpieces of Islamic art or mosques or arts themselves are affiliated with Islamic mosques.

\section{Judgmental view on the architecture of God's houses}

Islamic art is a legal art. The only knowledge that can understand and express Islamic art is wisdom. Architecture and related decorations have a very strong place in Islamic arts. The basis of Islamic architecture is based on wisdom. The wisdom of Islamic architecture, especially the architecture of mosques, can be studied in both external and internal dimensions. All the requirements and functions of mosques are wise both outwardly and inwardly. It is also possible to observe the outward and inward wisdom of the architecture of mosques in terms of the use of the symbolic, physical and operational functions, and the outward and inward characteristics of the constituents of the building. The historical course of mosque architecture itself illuminates the existence of wisdom in its transcendent meaning.

\section{Sacred art}

Sacred art is an art that, in addition to having a religious spirit and content, has a religious body and form, that is, it also has a religious identity. The facade is built in such a way that it is not different from other non-religious arts. Burckhardt exaggerates the symbolism of sacred art and believes his explanation. Sacred art has a special expression both in terms of form and meaning, and handicrafts are one of the fields of communication of this form and meaning. Therefore, a religious theme that is realistic, such as Renaissance art, cannot be a religious art because it lacks cryptography and specific stylistic allusions; it gives meaning to religious art [10]. 


\section{A) Characteristics of sacred art:}

Art is like a strong weapon in the hands of believers that has the power of transformation and can move people and make them strive to move [11].

- True art is directive.

- Moves and glides people towards infinity

- True art is committed and responsible to social currents

- Does not remain indifferent to oppression

- Makes a person move against the oppressors and exploiters

- True art seeks to fill social gaps

- True art helps us to develop our talents

- Committed art tries to find a way in which a person achieves happiness

- Committed art creates creation, Love of God revives love for people in hearts.

- Eliminates anger and hatred

- Committed art is creative and reveals the hidden [12].

B) The course of wisdom in the architecture of the house of God:

The art of architecture, especially the architecture of the mosque, has always had great wisdom throughout history. As mentioned in the previous sections, in a general summary, the manifestations of wisdom in architectural works can be divided as follows:

1- Meeting human needs to create a shelter for life and a place for solitude and worship and other needs;

2- Paying attention to the comprehensiveness of the building according to human needs;

3- Paying attention to the element of democracy, i.e. having a human scale in different elements of architecture;

4- Paying attention to the element of selfsufficiency, meaning that the architect and builder try to provide the required materials from the nearest places and at the lowest price.

5 - Avoiding futility in the sense that the architect and builder try to avoid useless elements and components. In fact, this principle of architecture existed before Islam and has also been considered after Islam.

6- Module, which was used to observe the proportions in classical Greek and Roman architecture, and is a means of adjusting the dimensions, size and geometry of the architectural guide in ensuring relations and principled harmony.

7- Introversion means placing architectural organs and constructing external walls, which enables the direct connection of the building with the outer space with an element called the courtyard. The introverted space pays attention to the inside from all sides.

Mosque architecture from the beginning of Islam (when the Messenger of God built the first mosque) to the present time and also mosques with new architecture have more or less had these manifestations of wisdom. Sometimes these manifestations of wisdom are highlighted, and sometimes diminished, which depends on the political, social and economic conditions of society.

\section{C) Judicial view of the appearance and interior of the house of God:}

The mosque is a manifestation of intuition. Intuition is the perfect truth that manifests itself in various forms. This semantic intuition can be seen in the faces of many pious people. There are semantic beauties in behavior and speech that give all the scent of the perfection of truth, and this perfection certainly brings beauty with it, because every truth is beautiful. In fact, art is a kind of truth since truth is always accompanied by beauty. Of course, a perfect truth is beautiful. In other words, the perfection of truth is beautiful.

\section{D) Judicial view on the functions of the house of God:}

One of the manifestations of wisdom in the structure of architectural buildings is their function. The existence of the function of the building and thinking about meeting the existing needs has been a sign of a very wide wisdom in the history of human architecture. Man has always sought to meet his needs, one of these needs is architecture and shelter. From the creation of man until now, he has sought to meet needs and achieve peace and comfort and has tried in this way. The construction of temples and shrines is also one of the inherent and natural needs of human beings; Because man has a Godseeking nature and seeks to reach the truth. So to meet this need, he worships God. The god of man was once made of stone and wood, once in the realm of stars and celestial bodies, and once sought among the myths. But eventually, with the advent of the prophets and their guidance, the man found the true God, that perfect truth, thus he needed a place to worship. Of course, temples existed before the advent of the prophets and among all tribes, and this issue itself indicates the natural need of man to worship, and the God-seeking nature of man always seeks the truth. Therefore, the need led to the construction of temples. With the advent of Islam, the need for a place to hold prayers and worship God 
led to the construction of the first mosque in Medina by the Holy Prophet.

Grand mosques were the best mosques in any city. These mosques were located in the city center and most of them were built next to the bazaar and the Government House. The most important function of the grand mosques of each city was to hold Friday prayers. In every city, prayers were held only on Friday noon at the Grand Mosque. So these mosques were mostly built in terms of size, since they could accommodate a large number of worshipers, depending on the city in which they are located. The courtyard of the Grand Mosque was an open space that, in addition to accommodating a large number of worshipers, made the worshiper feel closer to the sky and remember the extent of divine mercy.

One of the most important functions of mosques is the educational function. In Islam, there has always been a lot of emphasis on education and training, and Muslims have paid attention to this issue since the early years of Islam. The mosque has been the main base of education in Islamic society. After or before the daily prayers, question-andanswer sessions were held in mosques, and young Muslims sat around the master and used his lessons. With the passage of time and the growth and development of Islamic societies, as well as the greater attention of Muslims to education, these sessions were transferred to schools so that the resulting controversies of those circles of education would not disturb the worshipers.

One of the important functions of mosques is its social work function. From the beginning of Islam until now, the mosque was the place and home of hope for the needy, the afflicted and the travelers who were strangers in that city. For this purpose, places were built in many local mosques to help this group of people. Using verses with Quranic meanings and the theme of charity and helping the needy in the form of inscriptions in every corner of the mosque is a kind of response to this need of society and is itself a manifestation of wisdom in building Islamic mosques. The existence of a stone pool of water in the center of the courtyard of the mosque for purification and ablution shows the existence of great wisdom in the construction of the components of the mosque. This pool of water, in addition to providing the water needed for ablution, is a symbol of purity and clarity of the heart of the worshiper. Water is a sign of purity and mercy, the presence of which adds to the sanctity and purity of the mosque.

\section{CONCLUSION}

The relics and buildings left over from the behavior of their predecessors are the most useful tools in rereading the spiritual and epistemological foundations of Islamic architecture. Iranian architecture is the result of the spiritual view of our benevolent ancestors, so any time these works are re-examined, it can pave the way for the discovery of hidden concepts in its body; Concepts that have emerged from Iranian and Islamic spiritual teachings and have been expanded in material form. One of the most important teachings of Islamic architecture is annihilation in God. The connection between the arts is a field that can lead the various components of the universe to a transcendent unity. In the golden age of Islamic architecture in Iran, this unity and harmony has not crystallized in the ideal state. For example, we can refer to the construction of Sheikh Lotfollah Mosque in Isfahan. In this mosque, what we find in painting is what we see in the ruling Eslimi scripts, and what is seen in appearance is what is felt inside the walls. Most important of all, what is seen inside the building is the same as what we see outside.

\section{Competing interests}

The authors declare that they have no competing interests.

\section{REFERENCES}

[1] Mohammadi Nejad M. (2004). Philosophy of Islamic architecture, journal. College of Fine Arts. 19. p.61. Google Scholar

[2] Nasr H (1997). Sadra of Shiraz in Islamic History and Philosophy, by Mohammad Sharif, University Publishing Center, Tehran.

[3] Nasr SH and Nașr H. (1996). The Islamic intellectual tradition in Persia. Psychology Press. Google Scholar

[4] Nasr H (1996). Islamic Art and Spirituality, translated by Rahim Ghasemian, Tehran, Office of Religious Studies of Art. Google Scholar

[5] Pirnia M (1990) Iranian architectural methods, Publishing Institute of Art, Tehran, pp. 9-13

[6] Brady V (1998). Art and spirituality. Situs Web: http://www.ru.org/81brady.html ; Google Scholar ; Link

[7] Spiritual Wisdom and Art (1978). Translated by Gholamreza Avani; Compiled by Gholamreza Avani, Tehran: Kroos Publications. 
[8] Briggs J, Peat FD. (2009). Seven life lessons of chaos: Spiritual wisdom from the science of change. Harper Collins. Google Scholar

[9] Bolkhari Ghahi H (1995). Terminologies and Compressions in Noble Quran. The first Congress of Iran History of Architecture and Urbanism, Bam, Kerman.

[10] Burckhardt T. (1997). Sacred Art: principles and methods. Translated from the French by Jalal
Sattari, Tehran: Soroush publications. Google $\underline{\text { Scholar }}$

[11] Karami B, Nahidiazar F. (2012). Wisdom of Islamic art in Iranian mosques as artistic manifestation in history and Iran cultural heritage. Advances in Environmental Biology. 2012 Sep 1:2597-602. Google Scholar ; Link

[12] Wisdom and spiritual art (collection of articles) (1978). Compiled by Gholamreza Avani, Tehran: Kroos Publications. 